\title{
Modelling of Contaminant Mass Transport in Groundwater Flow Polluted by Sulphuric Goudron Pools of Incukalns
}

\section{Inčukalna sērskābā gudrona dīḳu piesārṇotā pazemes ūdens kustības datormodelēšana}

\author{
Aivars Spalvin̄š ${ }^{1}$, Inta Lāce ${ }^{2}$, Kaspars Krauklis ${ }^{3}$, Tatjana Sorokina ${ }^{4}$, Henning Wallner ${ }^{5}$ \\ ${ }^{1-3}$ Rìgas Tehniskā universitāte, Latvija, ${ }^{4,5}$ SIA Intergeo Baltic
}

\begin{abstract}
Kopsavilkums - Inčukalna novadā Rīgas smērvielu rūpnīca divus grants karjerus no 1955 . līdz 1970. gadam izmantoja kā izgāztuves škiidra gudrona (sērskābes un naftas produktu maisījums) glabāšanai. Šĩs izgāztuves nosauktas par Ziemeḷu un Dienvidu dīḳiem. Ziemeḷu dīķis ir aizbērts ar smiltīm, bet Dienvidu dīḳi šobrīd atrodas šḳidrs, pastveida un sacietējis gudrons. Jau 60 gadus abi dīḳi piesārņoja pazemes ūdeṇus, kuri virzās uz Gaujas upi. Ir uzsākta Dienvidu dīḳa satura ekskavācija. Paredzēts aizvākt ar gudronu piesārṇotās Ziemeḷu dīḳa smiltis. Lai optimizētu jau uzsāktos vides atveseḷošanas darbus, Rīgas Tehniskās universitātes speciālisti firmas INTERGEO uzdevumā veica piesārņojuma, īpaši virsmas aktīvo vielu (VAV), masas transporta datormodelēšanu. Aprēḳināts, ka Ziemeḷu un Dienvidu dīḳu VAV sasniegs Gaujas upi pēc aptuveni 25 un 80 gadiem (skaitot no 2015. gada). Upē ieplūdušo VAV masa praktiski neietekmēs upes ūdens kvalităti, jo, upes ūdenim sajaucoties ar VAV, daudzkārt samazinās VAV koncentrācija upē. Novērtēta sanācijas pasākumu, kuri jāveic pēc dīḳu satura ekskavācijas, efektivitāte.
\end{abstract}

Atslēgas vārdi - Hidroğeologiskais modelis, masas transporta modelēšana, virsmas aktīvās vielas (VAV).

\section{IEVADS}

Inčukalna pagastā eksistē vēsturisks pazemes ūdens piesārn,ojums, kura avots ir toksisko atkritumu izgāztuves divos grants karjeros. Tos laikā no 1955. līdz 1970. gadam piepildīja ar rūpniecības atkritumiem - sērskābo gudronu. Šī viela ir naftas produktu un sērskābes maisījums. Tā izveidojās Ziemeḷu (1955. g.) un Dienvidu (1965. g.) dīḳu izgāztuvēs, kuras piesārṇo pazemes ūdeni arī mūsdienās. Piesārṇotais ūdens lielā dziḷumā ( 50 metri no zemes virsmas) smilšakmens slān̄̄ pārvietojas uz Gaujas upi. Piesārṇojuma areāli skatāmi 1. attēlā.

Rīgas Tehniskās universitātes (RTU) Vides modelēšanas centra (VMC) speciālisti ar datormodelēšanas līdzekḷiem ir ieguvuši prognozi par piesārņojuma kustību no abiem dīķiem [1]. Prognoze ir skatāma 2. attēlā, kur parādīti galvenie dīḳu radītā piesārṇojuma ceḷi laikā no abu dīḳu eksistences sākuma. No 2. attēla var secināt, ka Ziemel̦u un Dienvidu dīķu radītais piesārnojums sasniegs Gaujas upi attiecīgi 2035. un 2095. gadā. Ja par laika atskaites sākumu mūsdienās izvēlas 2015. gadu, tad tas notiks attiecīgi pēc 20 un 80 gadiem.
Šobrīd tiek īstenota abu gudrona dīķu sanācija. Tā šiem dīḳiem ir atšķirīga, jo Ziemeḷu dīḳ̄ gudrons ir sajaukts ar smiltīm, bet Dienvidu dīḳi veido šķidrs, pastveida un sacietējis gudrons, kas piepilda smilšu karjeru. Tāpēc Dienvidu dīḳim ir iespējama gudrona ekskavācija, bet Ziemel̦u dīḳ̄ var aizvākt tikai dal̦u no smilšu un gudrona maisījuma. Arī hidroǵeoloǵiskie apstākḷi, kuri izsauc pazemes ūdens piesārņojumu, ir abiem dīḳiem atšḳirīgi.

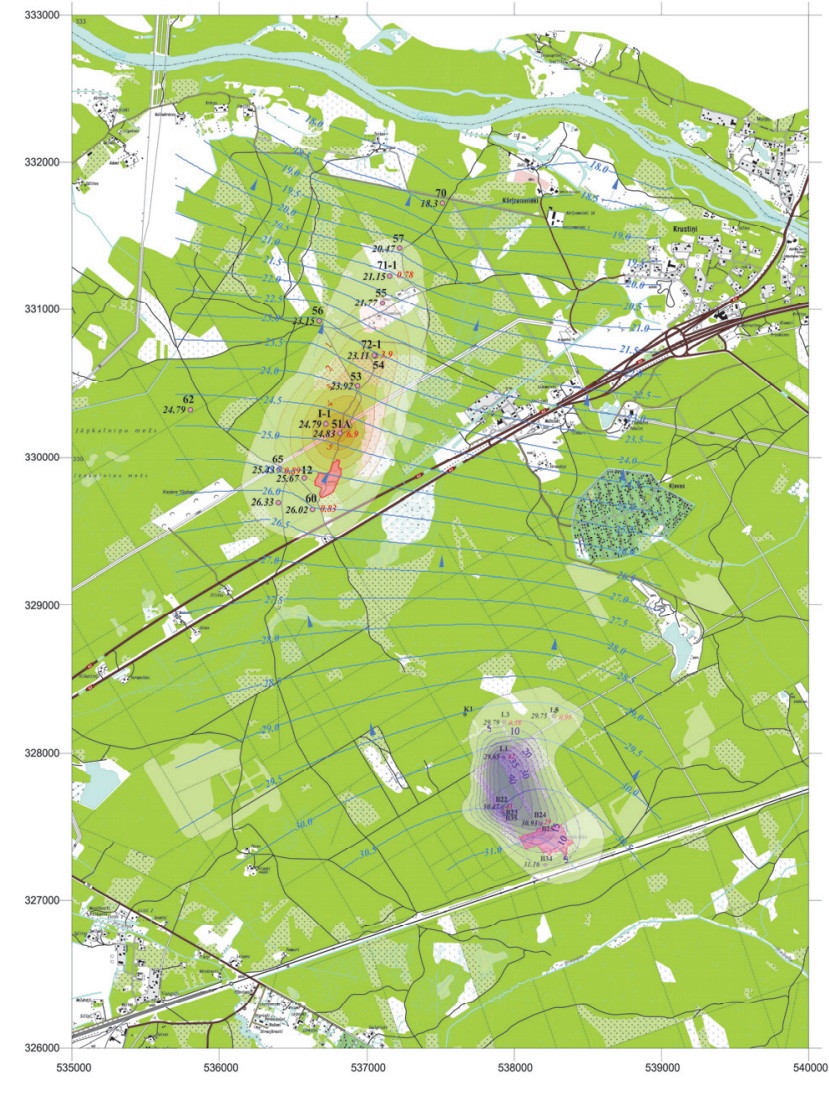

1. att. Ziemeḷu un Dienvidu dīḳa piesārṇojuma areāli.

Kaitējumu dabai var nodarīt pazemes ūden̄̄ izšḳīdušās virsmas aktīvās vielas (VAV), kuras ir l̦oti toksiskas. To piel̦aujamā koncentrācija rūpnieciskajam un dzeramajam ūdenim ir $0,3 \mathrm{mg} / \mathrm{l}$ un $0,03 \mathrm{mg} / \mathrm{l}$. 
VMC speciālisti 2016. gadā, īstenojot personu apvienības INTERGEO pasūtījumu, veica Ziemel̦u un Dienvidu dīķa hidroǵeoloǵisko apstākḷu datormodelēšanu. Pētījumā tika precizētas prognozes par VAV masas transportu pazemes ūdeņos un novērtēta sanācijas pasākumu efektivitāte, kuri īstenojami pēc gudronu dīḳu satura aizvākšanas.

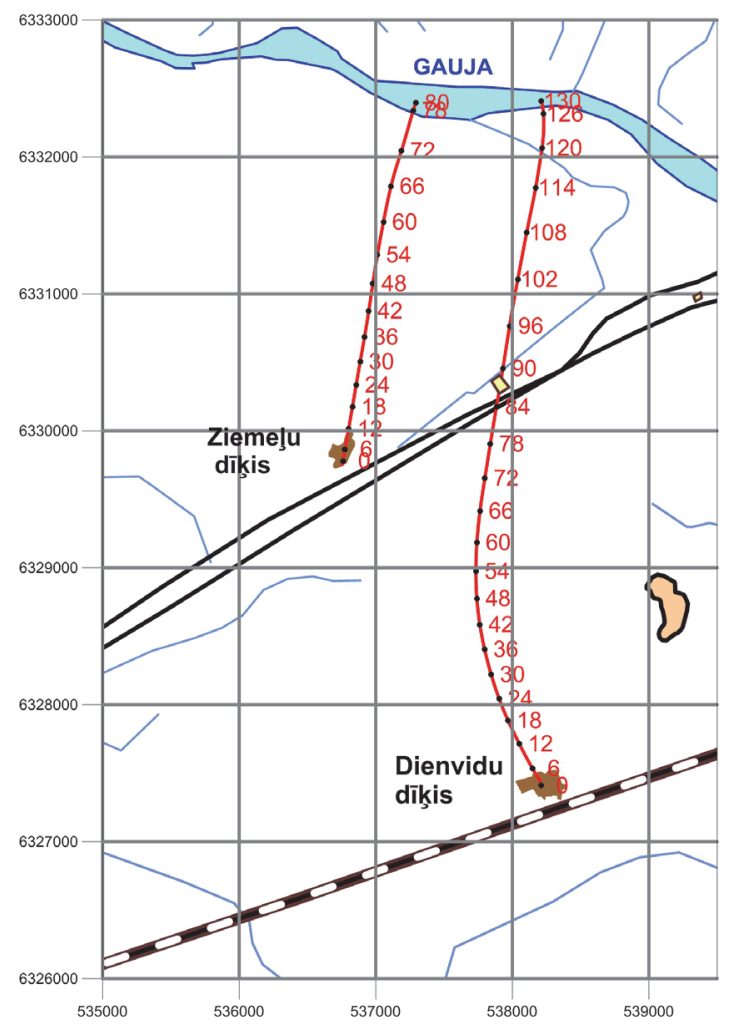

2. att. Ar MODPATH sistēmu prognozētā piesārṇojuma kustība no Ziemeḷu un Dienvidu dīksa uz Gaujas upi.

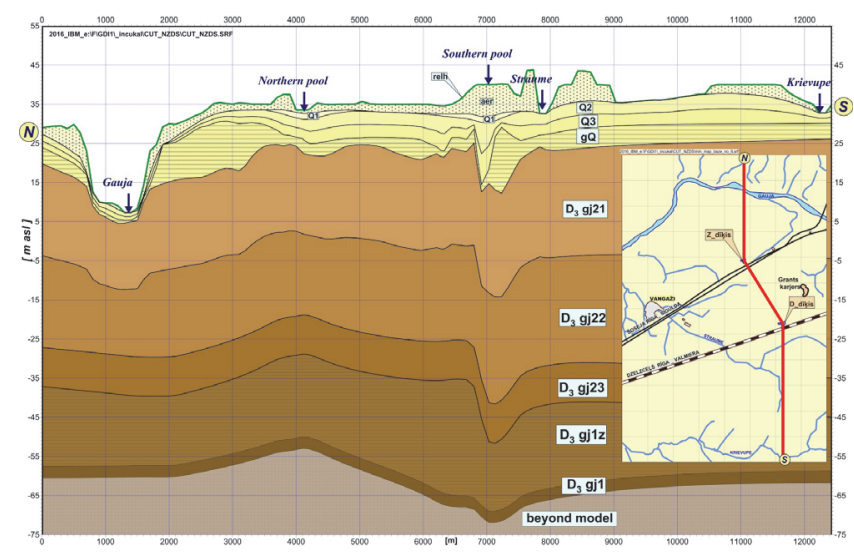

3. att. Vertikālais griezums caur Ziemeḷu un Dienvidu dīḳi.

Rakstā izmantoti pārskata [1] materiāli. Datormodelēšanai izmantots Inčukalna teritorijas hidroǵeoloǵiskais modelis (HM), kura apraksts dots pielikumā. HM darbojas licenzētas programmas Groundwater Vistas (GV) vidē [2]. GV sastāvā tiek izmantotas programmatūras MODFLOW (HM realizācija) [3]; MODPATH [4] un MT3D [5] (piesārṇojošo vielu kustības un masas transporta prognozēšanas modeḷi).
Modelēšanas rezultātu grafisko materiālu sagatavošanai izmantota sistēma SURFER [6].

\section{VIRSMAS AKTĪVO VIELU MASAS NOVĒRTĒJUMS}

VAV masas lielums abu gudrona dīḳu areālos tika novērtēts 2005. gadā [7], lai pamatotu ES līdzekḷu pieškiršanu gudrona dīḳu sanācijai. Toreiz VAV masa tika aprēḳināta pilnam smilšakmens slāṇa D3gj2 piesārņotajam tilpumam. Šis aprēḳins 2016. gadā bija būtiski jākoriǵē, jo tika konstatēts, ka VAV piesārṇo tikai š̄ slāņa apakšējo daḷu. Inčukalna HM vertikālā shematizācija (1p. tab. pielikumā) paredz, ka slānis D3gj2 ir sadalīts trīs apakšslāņos D3gj21, D3gj22, D3gj23 (3. att.). Slānis D3gj23 ir 10 metrus biezs, bet slāṇu D3gj21 un D3gj22 biezumi ir vienādi. Reālais slāņa D3gj2 piesārņotās daḷas biezums nav zināms, tomēr nosacīti pieņemts, ka VAV atrodas tikai slānī D3gj23. Koriḡètā prognoze VAV masai 2005. gadam skatāma I tabulā [1], kur VAV masa ir samazināta 6 reizes, salīdzinot ar sākotnējo prognozi 2005. gadā [7], jo VAV piesārņo tikai slāņa D3gj2 apakšējo daḷu.

VAV masas aprēḳinā un VAV masas transporta modelēšanā ar MODPATH un MT3D sistēmām visiem HM slāņiem ir izmantota efektīvās porainības vērtība 0,27.

I TABULA

KORIG̣ĒTĀ PROGNOZE PAR VAV PIESĀRṆOJUMU GAUJAS HORIZONTĀ D3GJ2 ZIEMEḶU UN DIENVIDU DĪḲA AREĀLĀ 2005. GADĀ

\begin{tabular}{|l|l|l|l|}
\hline N.p.k. & \multicolumn{1}{|c|}{ Parametrs } & $\begin{array}{c}\text { Ziemel̦u } \\
\text { dīḳis }\end{array}$ & \multicolumn{1}{|c|}{$\begin{array}{c}\text { Dienvidu } \\
\text { dīkiis }\end{array}$} \\
\hline 1 & Piesārṇotais laukums, ha & 108 & 91 \\
\hline 2 & $\begin{array}{l}\text { Piesārṇotā D3gj23 horizonta } \\
\text { biezums, m }\end{array}$ & 10 & 10 \\
\hline 3 & $\begin{array}{l}\text { Piesārṇotais horizonta tilpums, } \\
\mathrm{m}^{3}\end{array}$ & $10,8 \times 10^{6}$ & $9,1 \times 10^{6}$ \\
\hline 4 & Piesārṇotā ūdens tilpums, $\mathrm{m}^{3}$ & $2,92 \times 10^{6}$ & $2,46 \times 10^{6}$ \\
\hline 5 & Virsmas aktīvo vielu masa, kg & $17,5 \times 10^{3}$ & $20,9 \times 10^{3}$ \\
\hline 6 & $\begin{array}{l}\text { Vidējā virsmas aktīvo vielu } \\
\text { koncentrācija, mg/l }\end{array}$ & 6,0 & 8,5 \\
\hline 7 & $\begin{array}{l}\text { Piesārn̦ojuma masas } \\
\text { samazinājums, reizes }\end{array}$ & 6,06 & 6,27 \\
\hline
\end{tabular}

Prognozētā VAV piesārṇojuma dati 2015. gadā skatāmi II tabulā [1], kurā ņemts vērā, kā 2015. gadā ir izmainījušās abu dīḳu areālu vidējās VAV koncentrācijas: Ziemeḷu dīḳim $(6,0 \rightarrow 2,8) \mathrm{mg} / \mathrm{l}$; Dienvidu dīksim $(8,5 \rightarrow 12,7) \mathrm{mg} / \mathrm{l}$. Tāpēc notikusi VAV areālu masas izmaiṇa, salīdzinot ar 2005. gadu.

II TABULA

PROGNOZĒTAIS VAV PIESĀRNOJUUMS 2015. GADĀ GAUJAS HORIZONTĀ D3GJ2

\begin{tabular}{|c|l|l|l|}
\hline N.p.k. & Parametrs & Ziemeḷu dīksis & Dienvidu dīḳis \\
\hline 1 & VAV masa 2005. g., kg & $17,5 \times 10^{3}$ & $20,9 \times 10^{3}$ \\
\hline 2 & $\begin{array}{l}\text { Vidējā VAV } \\
\text { koncentrācija, mg/1 }\end{array}$ & 2,8 & 12,7 \\
\hline 3 & VAV masa 2015. g., kg & $8 \times 10^{3}$ & $30,5 \times 10^{3}$ \\
\hline 4 & $\begin{array}{l}\text { Izmaiṇa attiecībā pret } \\
\text { 2005. gadu, reizes }\end{array}$ & 0,46 & 1,49 \\
\hline
\end{tabular}

VAV masas samazināšanos Ziemeḷu dīḳa piesārņotajam areālam var izsaukt dīḳa pamatnes grunts poru piesārņojums ar naftas produktiem, kā arī VAV sabrukšana.

Iespējams, ka VAV noplūdes palielinājumu Dienvidu dīḳim var saistīt ar gudrona ekskavācijas darbu ietekmi. 


\section{AR SISTĒMU MODPATH IEGŪTĀS PROGNOZES}

Sistēma MODPATH [4] prognozē ūdens daḷiņu kustības trajektoriju telpā un laikā. Ar š̄is sistēmas palīdzību iegūts 2. attēla rezultāts par VAV kustību uz Gaujas upi. Ar MODPATH noskaidrots, ka VAV piesārṇojums caur sprostslāni D3gj1z var sasniegt slāni D3gj1 pēc 1000 gadiem, t. i., horizonta D3gj1 piesārn,ošanas iespēja ar VAV ir maza.

\section{AR SISTĒMU MT3D IEGŪTĀS PROGNOZES PAR VAV MASAS IZMAINU LAIKĀ}

Sistēma MT3D [5] aprēḳina piesārṇojošo vielu masu, tās kustību un arī piesārņojuma koncentrāciju laikā un telpā. Ziemeḷu un Dienvidu dīḳa piesārnotajam areālam aprēkināta VAV masa, ja nav vai ir veikta dīķa satura ekskavācija un ja nenotiek vai notiek VAV sabrukšana (nelabvēlīgs un optimistisks variants).

Ja notiek VAV sabrukšana, tad VAV koncentrācijas $c_{t}$ izmaiņu laikā $t$ dod formula [8]:

$$
c_{t}=c_{0} / \exp \left(0.7 / t_{0.5}\right)
$$

kur $c_{0}$ ir VAV sākuma koncentrācija; $t_{0,5}$ ir VAV s sabrukšanas konstante, kas vienāda ar laiku, kurā $c_{0}$ samazinās divas reizes. Datormodelēšanai izmantots $t_{0,5}=15$ gadi, kura vērtība rekomendēta monogrāfijā [8].

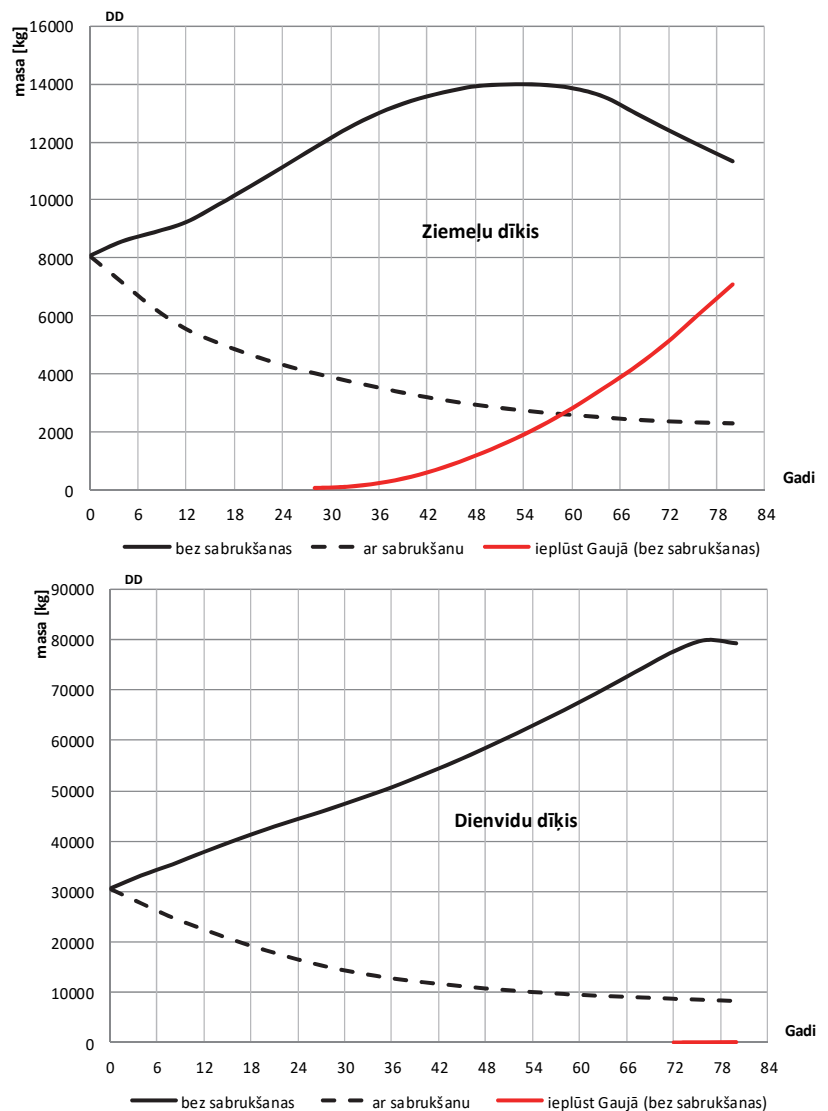

4. att. Ar $M T 3 D$ sistēmu prognozētā VAV masas izmaina Ziemelu un Dienvidu dīka apkārtnē piesārnotajā areālā bez un ar VAV sabrukšanas ievērošanu, ja nav veikta dīḳu sanācija.
Šobrīd nav eksperimentālu datu, kuri dotu iespēju noteikt reālo $t_{0,5}$ vērtību (iespējams, ka tā mainās laikā VAV novecošanās procesa ietekmē). Tomēr, īpaši Ziemeḷu dīḳa VAV areālam, arī $t_{0,5}=15$ gadi dod vērtīgu prognozi par VAV sabrukšanas būtisko ietekmi vismaz 80 gadu ilgam laikam.

Ar MT3D sistēmu aprēkinātā VAV masas izmaiņas grafiki abiem dīķiem ir skatāmi 4. attēlā (nav gudrona ekskavācijas) un 5. attēlā (ir notikusi dīḳu satura ekskavācija).

Vislielākā praktiskā nozīme ir Ziemelu dīḳa VAV areāla kustības pētīšanai, jo tas jau pēc 20-25 gadiem sasniegs Gaujas upi, bet no Dienvidu dīḳa VAV sāks ieplūst upē tikai pēc 75-80 gadiem (4. att. apakšējais grafiks).

Ja nenotiek dīku satura ekskavācija un nav VAV sabrukšanas, tad VAV masa Ziemel̦u un Dienvidu dīḳa areālam pieaug 1,75 un 2,66 reizes, salīdzinot ar 2015. gada stāvokli (4. att.).

Ja dīku saturs ir aizvākts (5. att.), VAV masa sāk samazināties ar to brīdi, kad VAV areāls sasniedz upi. Ja notiek VAV sabrukšana, tad variantā ar eskavētiem dīķiem pēc 80 gadiem ǵeoloǵiskā vidē praktiski nav VAV piesārņojuma. Ja dīḳi nav eskavēti, tad pēc 80 gadiem pazemes ūden̄i saglabājas VAV (attiecīgi $\sim 2000 \mathrm{~kg}$ un $\sim 10000 \mathrm{~kg}$ Ziemel̦u un Dienvidu dīķa areālam. Tāpēc dīḳu satura ekskavācija ne tikai aptur to teritorijas piesārṇošanu, bet arī sekmē pašattīrīšanās procesu dabā.
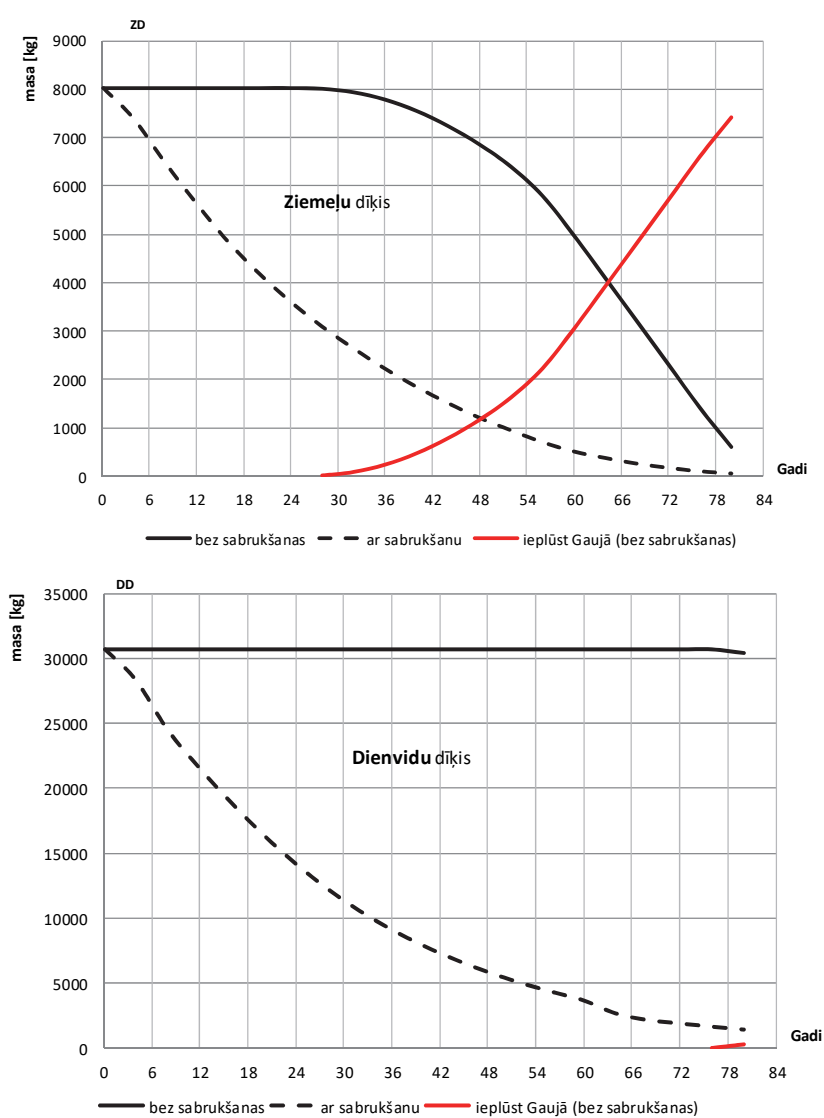

5. att. Ar $M T 3 D$ sistēmu prognozētā VAV masas izmaina Ziemeḷu un Dienvidu dīka apkārtnē piesārnotajā areālā bez un ar VAV sabrukšanas ievērošanu (ja veikta pilnīga abu dīḳu sanācija). 
$2016 / 55$
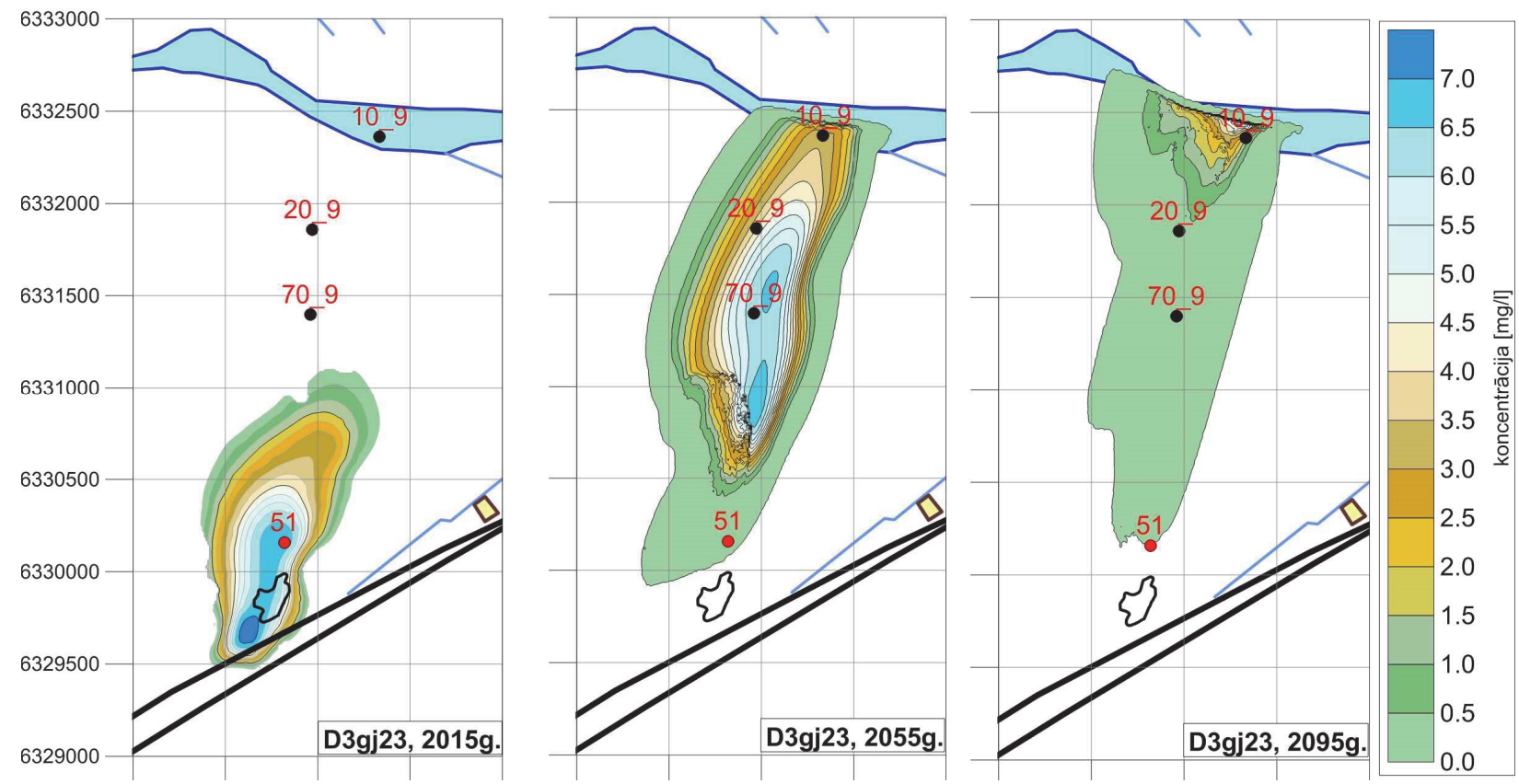

6. att. Ar MT3D sistēmu iegūtais VAV areāla koncentrāciju sadalījums D3gj2 horizontā Ziemeḷu dīḳim, neievērojot VAV sabrukšanu, ja veikta pilnīga dīḳa sanācija.
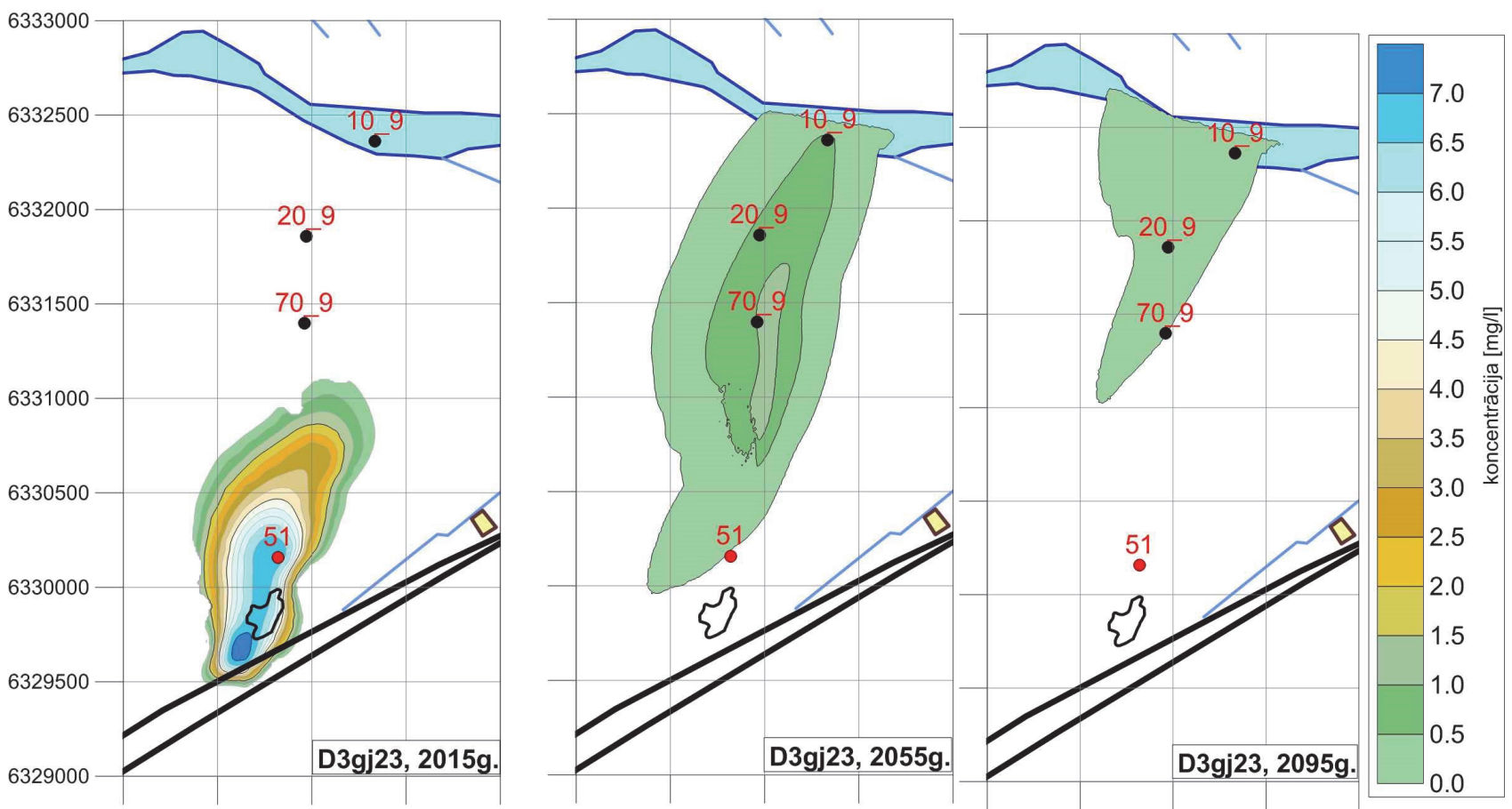

7. att. Ar MT3D sistēmu iegūtais VAV areāla koncentrāciju sadalījums D3gj2 horizontā Ziemeḷu dīḳim, ievērojot VAV sabrukšanu, ja veikta pilnīga dīḳa sanācija. 
Gaujā ieplūdušās VAV masas grafiks 5. attēlā Ziemeḷu dīkim liecina par to, ka laika gaitā palielinās VAV masas ieplūdes ātrums. Ja laiku no 24. gada līdz 84. gadam sadala trīs 20 gadu garos posmos, tad to laikā Gaujas upē ieplūst attiecīgi $660 \mathrm{~kg}, 2800 \mathrm{~kg}$ un $4000 \mathrm{~kg}$ VAV masas, ja nav VAV sabrukšanas. Šeit nosacīti pieņemts, ka pēc 24 gadiem (attiecībā pret 2015. gadu) Ziemeḷu dīḳa areāla fronte sasniedz upi.

VAV ieteces nevienmērību izsauc Ziemel̦u dīksa VAV areāla raksturs, jo tā perifērijā, arī frontes daḷā, VAV koncentrācija ir daudz mazāka nekā areāla kodolā. Šī apstākḷa ietekme uz areāla kustību ir aplūkota nākamajā iedaḷā.

\section{AR SISTĒMU MT3D IEGŪTĀS PROGNOZES PAR ZIEMELU DĪḲA VAV AREĀLA KUSTĪBU}

Rakstā analizēti tikai Ziemeḷu dīḳa VAV areāla kustības modelēšanas rezultāti, jo šis areāls Gauju sasniegs jau tuvā nākotnē. Modelēšanas dati par Dienvidu dīķa VAV areālu atrodami pārskatā [1].

Ar sistēmu MT3D aprēḳinātie VAV areāla stāvokḷi 2015., 2055. un 2095. gadā skatāmi 6. attēlā un 7. attēlā attiecīgi nelabvēlīgam un optimistiskam VAV uzvedības rakstura gadījumam (nav vai ir VAV sabrukšana). Šie attēli dod papildu skaidrojumu upē ieplūdušās VAV masas izmaiņai:

- laika gaitā VAV dispersijas ietekmē pieaug areāla laukums un VAV koncentrācija areāla perifērijā ir mazāka nekā areāla kodolā (salīdzinot 2015. un 2055. gada areālu 6. att.);

- ja notiek VAV sabrukšana, tad samazinās VAV koncentrācija tā areālā (salīdzinot 2055. gada areālu 6. att. un 7. att.).

Dispersijas dēl areāla frontes dal̦ā ir relatīvi neliela VAV koncentrācija un 2055. gadā VAV kodols nebūs sasniedzis Gauju (6. att.). Tāpēc pēc 40 gadiem tikai $\sim 600 \mathrm{~kg}$ no $8000 \mathrm{~kg}$ VAV masas būs nokḷuvuši Gaujā (5. att. līkne VAV masai upē). Optimistiskajā variantā (ir VAV sabrukšana) pēc 40 gadiem D3gj2 slānī būs palikuši $2000 \mathrm{~kg}$ VAV, t. i., VAV masa sabrukšanas ietekmē samazinās vismaz divas reizes, bet Gaujā ieplūdušā VAV daudzums būs niecīgs. Pēc 80 gadiem (2095. g.) Gaujā būs nokḷuvis VAV areāla kodols (6. att.), un, ja nav VAV sabrukšanas, tad D3gj2 slānī būs palikuši $540 \mathrm{~kg}$ VAV (5. att.). Ja notiek VAV sabrukšana, tad D3gj2 slānī praktiski nebūs VAV piesārnojuma.

Ja nenotiek VAV sabrukšana, tad pēc Ziemeḷu dīḳa satura ekskavācijas tā piesārn,ojums horizontā D3gj2 būs izzudis pēc $\sim(100-120)$ gadiem.

\section{VAV KONCENTRĀCIJU HIDROGRĀFI VIRTUĀLAJOS MONITORINGA URBUMOS}

Sistēmā $M T 3 D$ var izveidot virtuālus monitoringa urbumus VAV koncentrāciju izmaiņu novērošanai laikā un telpā. Ziemel̦u dīksim tika izmantoti četri monitoringa urbumi D3gj23 apakšhorizontā (HM slānis Nr. 9). Šo urbumu novietojums skatāms 6 . attēlā:

- urbums Nr. 51 ir reāli eksistējošs urbums D3gj23 slānī, un tas atradās VAV areālā 2015. gadā;

- urbums Nr. 70-9 atradīsies VAV areāla kodola rajonā pēc 40 gadiem, taču to ātri sasniegs areāla frontes dala;

- urbumu Nr. 20-9 pēc 50 gadiem šḳērsos areāla kodols;
- urbums Nr. 20-10 atrodas Gaujas krastā, un tajā tiks reǵistrēta VAV koncentrācija upē ieplūstošajā pazemes ūdenī.

Urbumu novietojums izvēlēts tā, lai tie registrētu VAV koncentrāciju maksimumu VAV areāla kodolā.

VAV koncentrāciju hidrogrāfi virtuālajiem monitoringa urbumiem ir skatāmi 8. attēlā. Šeit doti hidrogrāfi abiem VAV uzvedības variantiem (nav vai ir VAV sabrukšana). Ja notiek VAV sabrukšana, tad notiek ne tikai VAV koncentrācijas samazināšanās, bet arī ātrāk parādās š̄is koncentrācijas maksimums (raustītā līnija 8. att.).
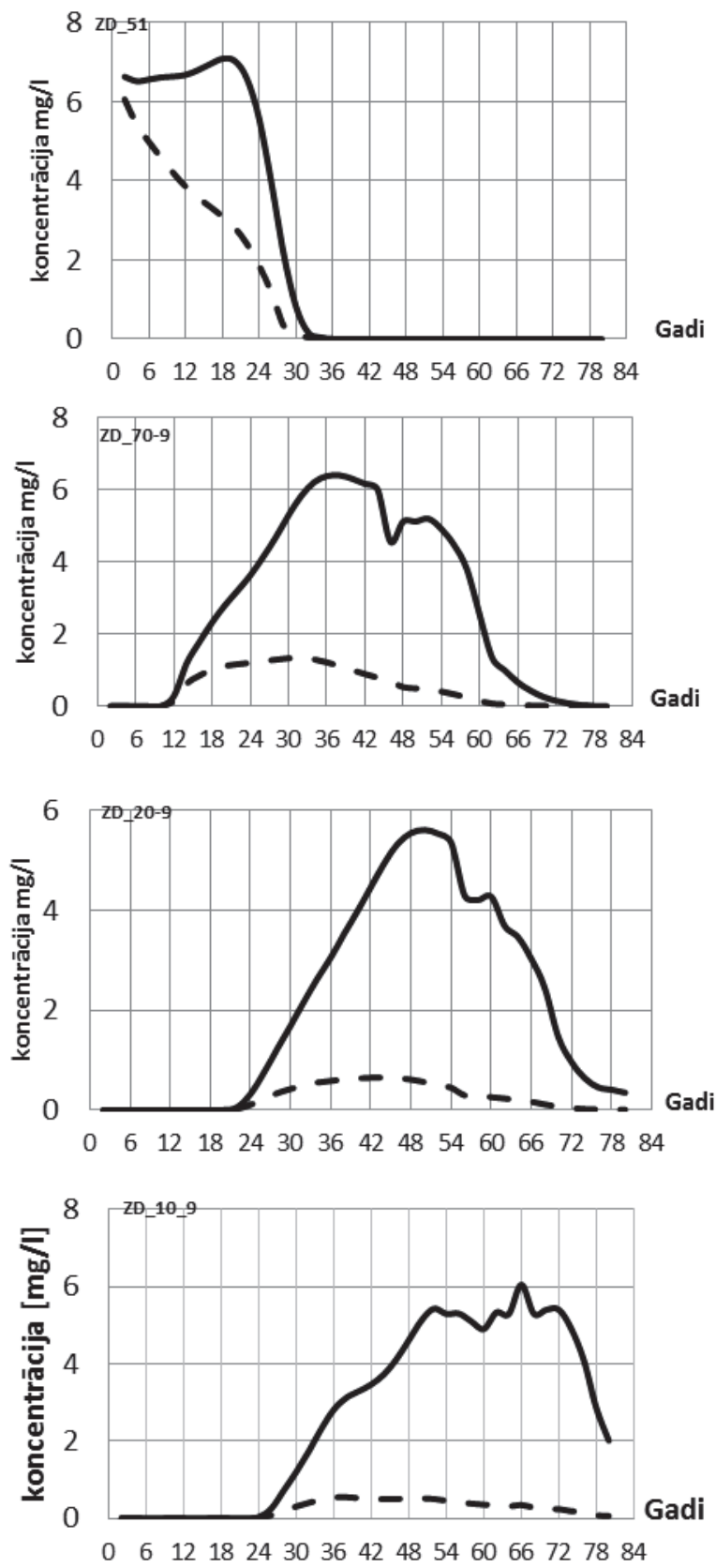

8. att. VAV koncentrāciju hidrogrāfi monitoringa urbumos Nr. 51, Nr. 70-9, Nr. 20-9, Nr. 10-9 Ziemel̦u dīķim, ievērojot vai neievērojot sabrukšanu, ja veikta piln̄̄ga dīḳa satura ekskavācija. 


\section{VAV KONCENTRĀCIJA GAUJĀ}

Ziemeḷu dīḳa piesārņotais pazemes ūdens nokḷūs Gaujā. VAV vidējo koncentrāciju $c_{\text {vav }}$ upē laika posmam $t$ var novērtēt ar attiecību:

$$
c_{\mathrm{vav}}=m_{\mathrm{vav}} / V_{\mathrm{Gauja}}
$$

kur $m_{\text {vav }}-$ upē ieplūdušā VAV masa laikā $t, \mathrm{~kg} ; V_{\text {Gauja }}-$ Gaujas upes ūdens tilpums, $\mathrm{m}^{3}$, kurš aiztecējis gar Inčukalnu laikā $t$. Masu $m_{\text {vav }}$ dod 5. attēla grafiks upē ieplūdušajām VAV. Nosacīti par laika atskaites sākumu pieņemsim 24. gadu (skaitīt no 2015. gada). Ūdens tilpumu $V_{\text {Gauja }}$ laikā $t$ dod izteiksme:

$$
V_{\text {Gauja }}=365 t v_{\text {Gauja }}
$$

kur $t$ ir laika posma garums gados; $v_{\text {Gauja }}$ ir upes caurtece, $\mathrm{m}^{3} / \mathrm{dnn}$. Novērtēsim $c_{\text {vav }}$ trīs 20 gadu laika periodiem: $t_{1}-$ no 24. līdz 44. gadam; $t_{2}-$ no 44 . līdz 64. gadam, $t_{3}-$ no 64 . līdz 84. gadam. Ja $t=20$ gadi, $v_{\text {Gauja }}=8500000 \mathrm{~m}^{3} / \mathrm{dnn}$ [9], [14], tad $V_{\text {Gauja }}=62,1 \times 10^{9} \mathrm{~m}^{3}$. Ja nav VAV sabrukšanas, $c_{\text {vav }}$ aprēķina rezultāts ir skatāms III tabulā.

III TABULA

VAV KONCENTRĀCIJA GAUJĀ, JA NAV VAV SABRUKŠANAS

\begin{tabular}{|c|c|c|c|}
\hline Periods* & $m_{\mathrm{vav}}, \mathrm{kg}$ & $V_{\text {Gauja }}, \mathrm{m}^{3}$ & $c_{\mathrm{vav}}, \mathrm{ng} / 1$ \\
\hline$t_{1}$ & 660 & $62,1 \times 10^{9}$ & 11,1 \\
\hline$t_{2}$ & 2800 & $62,1 \times 10^{9}$ & 46,6 \\
\hline$t_{3}$ & 4000 & $62,1 \times 10^{9}$ & 66,6 \\
\hline
\end{tabular}

No šīs tabulas var secināt, ka laikā $c_{\text {vav }}$ pieaug, taču tās vērtība ir tikai nanogrami uz litru. Ja upes mazūdens periodā $v_{\text {Gauja }}=1400000 \mathrm{~m}^{3} / \mathrm{dnn}$ [9], tad $c_{\text {vav }}$ pieaug sešas reizes.

VAV ieplūde Gaujā ar Ziemel̦u dīķa piesārņoto pazemes ūdeni praktiski neietekmē upes ūdens kvalitāti pat tajā gadījumā, ja nenotiek VAV sabrukšana.

Šāds rezultāts ir sekas apstāklim, ka pazemes ūdens daudzums un tā ieteces ātrums upē ir daudzkārt mazāks nekā vidējā Gaujas caurtece $\left(\sim 100 \mathrm{~m}^{3} / \mathrm{s}\right)$.

VAV areāla saskarsmes vietā ar upi ir iespējams lokāls kaitējums dzīvajai dabai, jo VAV sajaukšanās ar upes ūdeni nenotiek uzreiz.

\section{SANĀCIJAS PASĀKUMI ESKAVĒTO DĪḲU TERITORIJĀM}

Dīḳu satura ekskavācija nevar pilnīgi likvidēt gudrona paliekas to pamatnēs, īpaši Ziemeļu dīķim, kurā ir jānorok vispiesārņotākā smilšu un gudrona maisījuma daḷa. Arī Dienvidu dīḳ̄ var palikt ar gudronu piesārņotas smiltis. Šo iemeslu dēḷ dīķu areālos ir jāîsteno tādi sanācijas pasākumi, kuri pēc iespējas labāk novērstu gudrona atlieku izšḳ̄īināšanu ar pazemes ūdens plūsmām kvartāra smilšu slānī. Ir divi atšķirīgi pazemes ūdens plūsmu tipi:

- atmosfēras nokrišṇu radītā vertikālā infiltrācijas plūsma aerācijas zonā;

- horizontālā plūsma smilšu slānī.

Lai samazinātu vertikālās plūsmas ietekmi, abu dīḳu areāli ir jāpārklāj ar ūdensnecaurlaidīgu pretinfiltrācijas pārsegumu. Šis pārsegums praktiski novērš gudrona atlieku izšķ̄īdināšanu
Dienvidu dīkīi, jo tas atrodas aerācijas zonā, kurā nav horizontālās pazemes plūsmas [1]. Ziemeḷu dīḳa gudrona atliekas šķērso horizontālā plūsma, un tāpēc pretinfiltrācijas pārklājums tikai $\sim 3,5$ reizes samazinās gudrona izškīinināšanas intensitāti [1]. Var vājināt horizontālās plūsmas ietekmi ar sprostsienas ierīkošanu.

Ziemeḷu dīḳim vēlams veikt pazemes ūdens attīrīšanu.

\section{SECINĀJUMI}

Inčukalna gudrona dīḳu izraisītais piesārņojums pazemes ūdens plūsmā virzās uz Gauju. Šis process notiek jau 60 gadus, un abu dīķu piesārņojuma areālu kustību ar mūsdienu tehnoloǵijām nevar apturēt.

Īpaši lielu kaitējumu videi rada toksiskās virsmas aktīvās vielas (VAV). Firmas INTERGEO uzdevumā RTU VMC speciālisti veica VAV masas transporta modelēšanu pazemes ūdens plūsmā. Iegūti rezultāti, kurus var izmantot Inčukalna piesārṇotās ǵeoloǵiskās un hidroǵeoloǵiskās vides atveselıošanas darbos:

- jāpabeidz abu gudrona dīķu satura ekskavācija, jo tad tiks apturēta pazemes ūdens piesārṇošana un samazināsies laiks, kurā var notikt pazemes ūdeṇu un ǵeologiskās vides pašattīrī̌sanās;

- vides pašattīrīšanās notiek VAV sabrukšanas dēḷ un arī tāpēc, ka piesārņotais pazemes ūdens nonāks Gaujas upē;

- novērtēta VAV masa 2015. gadā abu dīķu piesārņojuma areāliem - attiecīgi $8000 \mathrm{~kg}$ un $30500 \mathrm{~kg}$ Ziemeḷu un Dienvidu dīķim.

- aprēķināts, ka VAV areāli sasniegs Gauju (skaitot no 2015. gada) pēc 20-25 un 75-80 gadiem attiecīgi Ziemeḷu un Dienvidu dīkim;

- veikta abu dīķu VAV areālu kustības modelēšana nākošajiem 80 gadiem (sākot no 2015. g.); konstatēts, ka, ja nav VAV s sabrukšanas, tad Ziemel̦u dīķa areāla VAV masas ieplūde Gaujā notiek šãdi: $660 \mathrm{~kg}$ laika posmā no 2039. līdz 2059. g.; $2400 \mathrm{~kg}$ - no 2059. līdz 2079. g.; $4000 \mathrm{~kg}$ - no 2079. līdz 2099. g.; pēc 2099. gada VAV areāla masa būs $540 \mathrm{~kg}$; VAV ieplūde ir nevienmērīga, tāpēc ka VAV koncentrācija areāla perifērijā (arī frontes daḷā) ir mazāka par VAV koncentrāciju areāla kodolā;

- ja VAV pussabrukšanas laiks ir 15 gadi, tad pēc 80 gadiem abu dīḳu VAV areāli ir pārstājuši eksistēt; t. i., ir notikusi ǵeolog̣iskās vides pašattīrīšanās;

- aprēkināta VAV koncentrācija Gaujā, kuru varētu izsaukt Ziemel̦u dīksa areāla ieplūde (ja nav VAV sabrukšanas): $11 \mathrm{ng} / \mathrm{l}$ laika posmā no 2039. līdz 2059. g.; $47 \mathrm{ng} / 1$ - no 2059. līdz 2079. g.; 67 ng/l - no 2079. līdz 2099. g., t. i., Ziemel̦u dīķa VAV areāla masas ieplūde upē neietekmē upes ūdens kvalitāti. Tikai VAV areāla ieteces apkārtnē iespējams kaitējums dabai, jo VAV ar upes ūdeni nesajaucas uzreiz.

- lai samazinātu gudrona atlieku radīto piesārņojumu, pēc abu dīḳu satura ekskavācijas tie jāpārklāj ar pretinfiltrācijas segumu; Dienvidu dīķa gudrona atlikums atrodas aerācijas zonā, un tāpēc pārklājums praktiski aptur gudrona nonākšanu pazemes ūden̄i; Ziemeḷu dīķim pārklājums samazina gudrona šķı̌šanu $\sim 3,5$ reizes, jo gudrona atlikumu apskalo horizontālā pazemes ūdens plūsma, kuras ietekmes samazināšanai var izmantot sprostsienu; vēlams veikt ar VAV piesārņotā pazemes ūdens attīrīšanu. 
Var secināt, ka modelēšanas rezultāti bagātina zināšanas par Inčukalna gudrona dīḳu problēmas optimālām risināšanas iespējām. Būtisks ir atzinums, ka aptuveni 80-100 gadu laikā var notikt pazemes ūdens un ǵeoloǵiskās vides pašattīirǐsanās. Piesārṇojums, kas nokḷūs Gaujā nevar ietekmēt tās ūdens kvalitāti, jo upes caurteces ietekme ir daudzkārt lielāka nekā upē ieplūdušajam piesārņojumam.

Inčukalna HM Gaujas pazemes pieteces kalibrēšanai ir izmantoti Latvijas hidroǵeologiskā modeḷa LAMO4 dati. LAMO4 veidots ar Latvijas valsts pētījumu programmas EVIDEnT atbalstu.

\section{PIELIKUMS. INČUKALNA TERITORIJAS HIDROG̣EOLOGISKAIS MODELIS}

Inčukalna HM novietojums skatāms 1p. attēlā. Modeḷa pirmā versija (1998. g.) izmantoja VMC speciālistu izveidoto Latvijas reǵionālā HM REMO vidi [10]. Modela 2. versija izveidota 2005. gadā [7]. Trešā 2016. gada HM versija kā bāzi izmantoja 2005. gada modeli. Visas trīs HM versijas imitē ilggadīgos vidējos hidroǵeoloǵiskos apstākḷus Inčukalna apkārtnē. 2016. gada HM darbojas licenzētas programmatūras GV vidē [2].

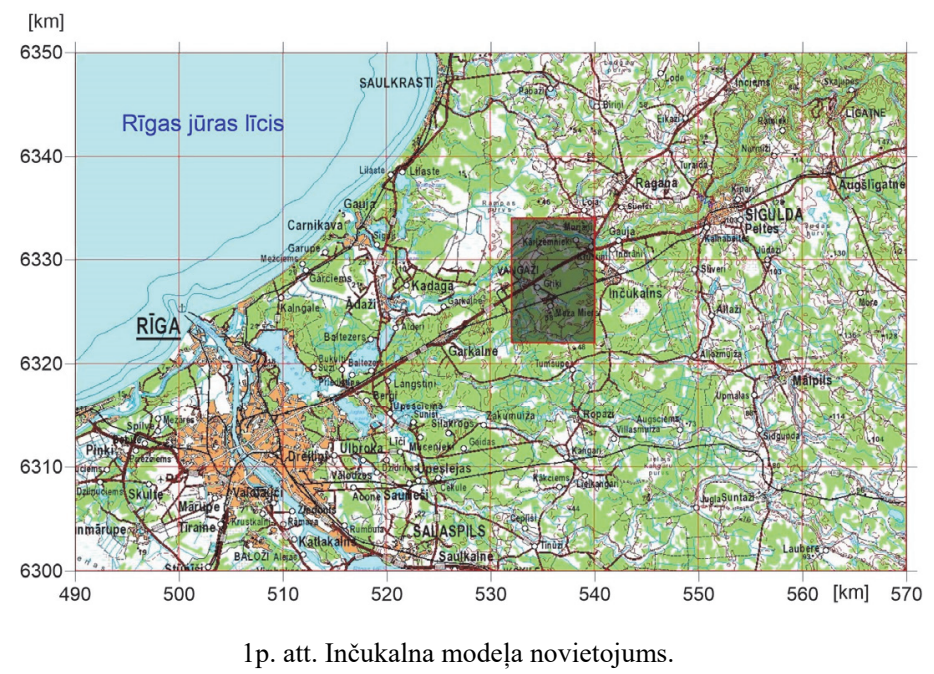

Inčukalna HM ietver $8000 \mathrm{~m} \times 12000 \mathrm{~m}$ laukumu. HM bāzes karte ar lokālajiem HM skatāma 2p. attēlā. Modeḷu 1998. un 2005. gada versijām režǵa plaknes solis bija 100 metri, bet Ziemeḷu un Dienvidu dīḳu lokālajiem HM plaknes solis bija 20 metri. 2012. gadā Ziemeḷu dīḳa lokālajam HM lietoja soli 10 metri [13]. VAV kustības modelēšanai 2016. gadā bija paredzēts izmantot apvienoto Ziemel̦u un Dienvidu dīḳu modeli, kura solis 10 metri un izmērs $4500 \mathrm{~m} \times$ 7000 m. Šim apgabalam modelī izmantoti pārskata [11], [12] dati, kuri iegūti no pētniecības urbumiem. Tāpēc šai HM daḷai ir augsta ǵeologiskās informācijas ticamība. Darba gaitā tika konstatēts, ka datora veiktspēja nodrošina modelēšanu visā HM apgabalā ar režǵa soli 10 metri. Tāpēc samazinātā izmēra apvienotais HM netika izmantots.

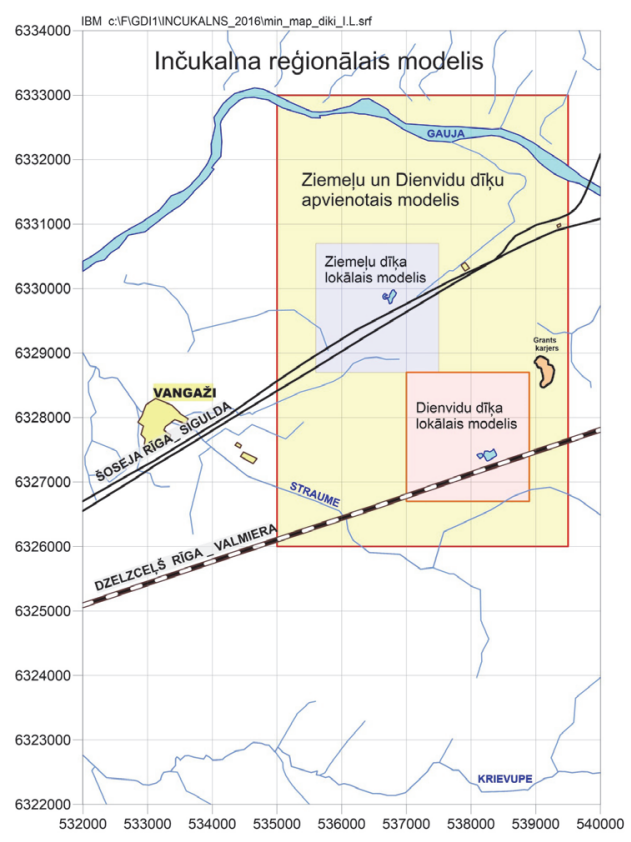

2p. att. Inčukalna modẹ̣a bāzes karte un lokālie hidroǵeologiiskie modeḷi.

HM vertikālā shematizācija ir vienota 2005. un 2016. gada modeḷa versijām un tā skatāma $1 \mathrm{p}$. tabulā.

1P.TABULA

INČUKALNA MODEḶA VERTIKĀLĀ SHEMATIZĀCIJA

\begin{tabular}{|c|c|c|c|}
\hline $\begin{array}{l}\text { Slāņa } \\
\text { tips }\end{array}$ & $\begin{array}{c}\text { Slāṇa } \\
\text { nosaukums }\end{array}$ & $\begin{array}{l}\text { Ģeologiskais kods } \\
\text { modelī }\end{array}$ & $\begin{array}{l}\text { Modeḷa sekcijas numurs un } \\
\text { tips }\end{array}$ \\
\hline & Reljefs & relh & 1. (robežnoteikums) \\
\hline & \multirow{5}{*}{ Kvartārs } & aer & 2. $(z)$ \\
\hline & & $Q 1$ & 3. $(x y)$ \\
\hline & & $Q 2$ & 4. $(x y)$ \\
\hline & & Q3 & 5. $(x y)$ \\
\hline & & $g Q$ & 6. $(z)$ \\
\hline & \multirow{3}{*}{ Otrā Gauja } & $D_{3} g j 21$ & 7. $(x y)$ \\
\hline & & $D_{3} g j 22$ & 8. $(x y)$ \\
\hline & & $D_{3} g j 23$ & 9. $(x y)$ \\
\hline & \multirow{2}{*}{ Pirmā Gauja } & $D_{3} g j 1 z$ & 10. $(z)$ \\
\hline & & $D_{3 g j 1}$ & 11. (robežnoteikums) \\
\hline
\end{tabular}

Modeli veido 11 slāņi. Pirmais un vienpadsmitais slānis tiek lietots pirmā veida robežnoteikumu (uzdoti ūdens līmeņi) fiksēšanai. Pirmajā slān̄̄ relh tiek uzdota zemes reljefa karte, bet vienpadsmitajā - Gaujas horizonta D3gj1 pjezometrisko līmeņu sadalījums. Kvartāra nogulumu slānis ir sadalīts piecos apakšslān,os: aer, Q1, Q2,Q3, gQ, bet Gaujas D3gj nogulumi tiek modelēti ar četriem slāņiem: D3gj21, D3gj22, D3gj23, D3gj1z. Slāṇi aer, gQ un D3gj1z ir sprostslāṇi. Slānis aer ir aerācijas zonas ekvivalents un tiek izmantots infiltrācijas plūsmas vadīšanai. G̦eologiskais griezums $S-N$, kurš šķērso abus dīķus, ir skatāms 3. attēlā.

Slānis Q1 eksistē tikai dīḳu apkārtnē (biezums 1,5 m) un nodrošina precīzāku gudrona dīḳu (īpaši Ziemeḷu) ietekmes modelēšanu. Slāṇu Q1 un Q2 biezumi ir vienādi. 
Smilšu slāṇa $Q$ sadalījums trīs apakšslānos nodrošina precīzāku datu iegūšanu par tiem sanācijas pasākumiem, kuri būs jāveic dīkiem pēc to satura ekskavācijas.

Arī smilšakmens ūdens horizonts D3gj2 ir sadalīts trīs apakšhorizontos, lai varētu ievērot piesārnojumu kustības telpisko raksturu un to nevienmērīgo koncentrāciju sadalījumu slānī. Apakšējais slānis D3gj23 2016. gada modelī tiek izmantots VAV koncentrācijas uzdošanai, jo 2015. gadā noskaidrots, ka VAV šeit ir maksimālā koncentrācija, slāņa D3gj23 biezums ir 10 metri. Slāṇiem D3gj21 un D3gj22 ir vienādi biezumi, un šajos slāņos VAV koncentrācija ir niecīga.

Par pazemes ūdens plūsmu ātrumu un virzienu ūdens horizontos var spriest pēc to pazemes ūdens līmeñu kartēm. Inčukalna gadījumā pazemes ūdens piesārnıošana notiek kvartāra smilšu slānī Q un smilšakmens slānī D3gj2. Šo slānnu ūdenslīmenuu izolīniju kartes ir skatāmas 3p. attēlā un 4 p. attēlā.

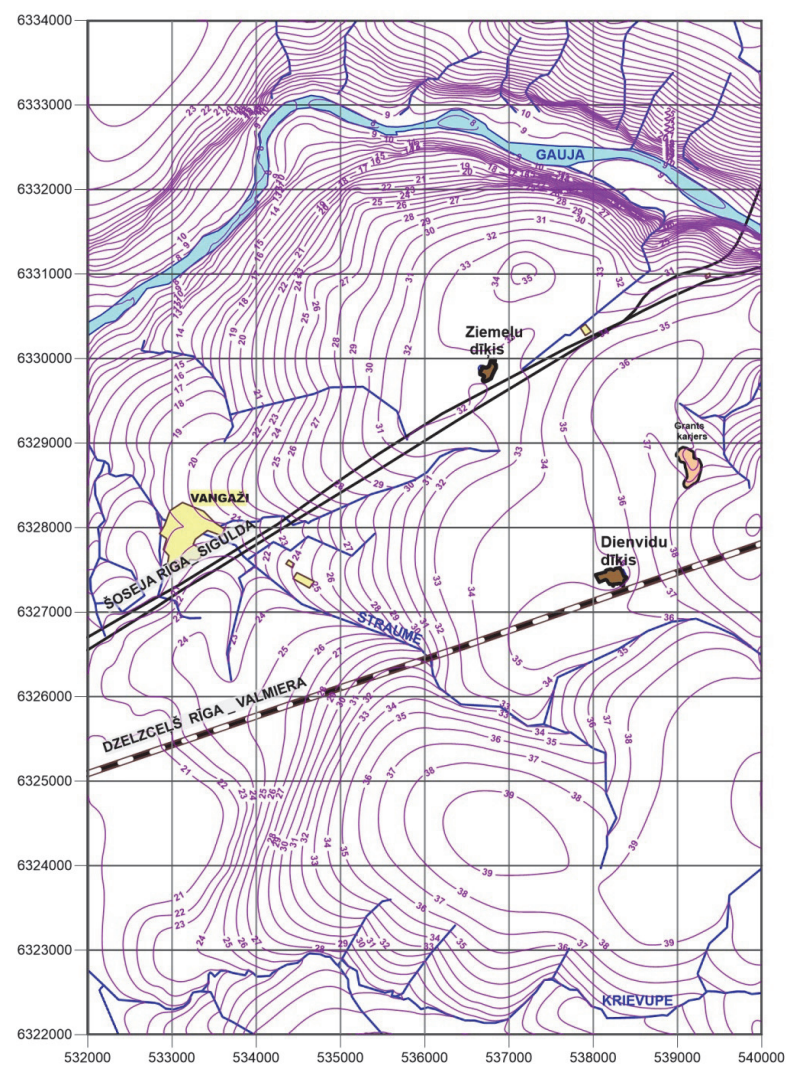

3p. Kvartāra horizonta Q ūdens līmeṇu izolīniju karte, m v.j.l.

Šīs kartes parāda, ka pazemes ūdens plūsmu raksturs Q un D3gj2 slāṇos ir atškirīgs, un tāpēc piesārnojuma kustības procesi šajos slānnos ir dažādi:

- Q slānī abu dīḳu apkārtnē ir niecīgs pazemes ūdens plūsmas gradients, tāpēc šeit piesārṇojums pārvietojas lēni, tā kustības virziens nesakrīt ar kustības virzienu D3gj2 slānī;

- D3gj2 slānī piesārṇojums no abiem dīkiiem virzās uz Gauju. Piesārṇojums šajā slānī nonāk no Q slāṇa, kur atrodas gudrona dīķi;
- hidroǵeoloǵiskie apstākḷi Ziemeḷu un Dienvidu dīkīi ir atškirīịi: Ziemeḷu dīḳis atrodas Q1 slānī, tāpēc tā saturu izškīidina horizontālā plūsma slānī un nokrišṇu (infilttrācijas) plūsma; Dienvidu dīḳis atrodas aer zonā, un te gudronu izšḳīinina nokrišṇu plūsma.

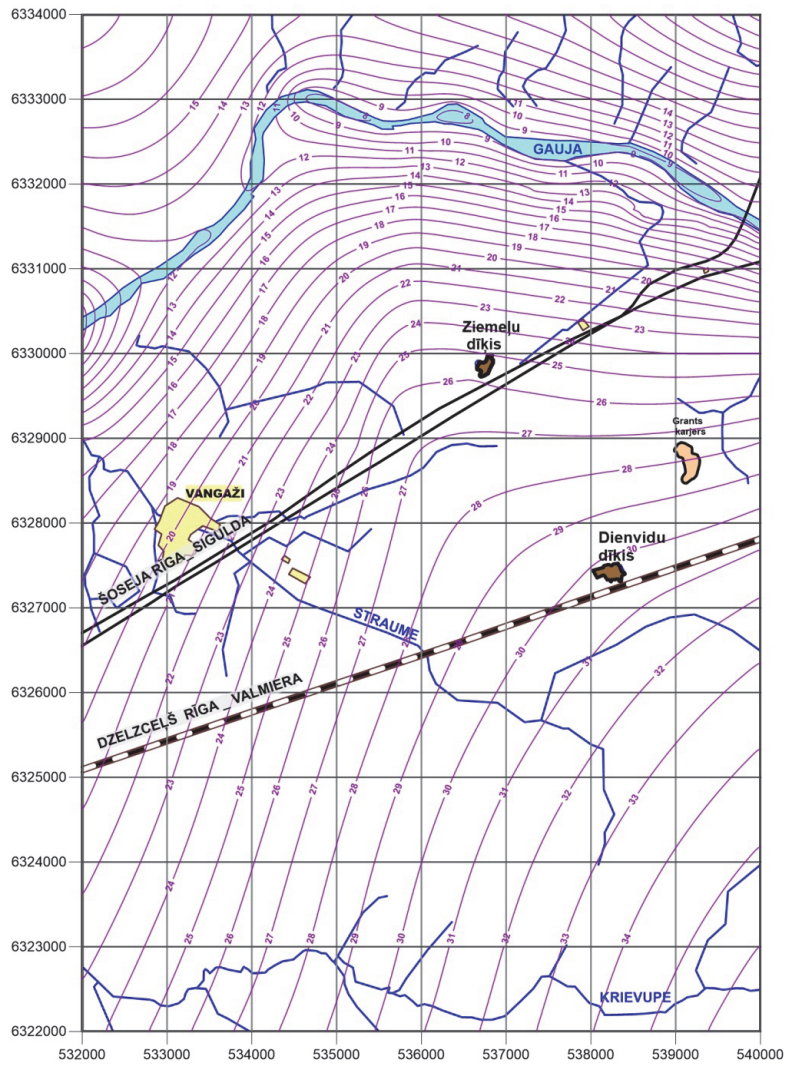

4p. att. Gaujas horizonta D3gj2 ūdens līmeṇu izolīniju karte, m v.j.1.

HM vidē darbojas GV modeli MODPATH un MT3D, kuri tika izmantoti VAV kustības prognozēšanai pazemes ūdens plūsmā. MODPATH izmanto ūdens plūsmas kustības pētī̌sanai ar virtuālo ūdens dalinu trasēšanas metodi (2. att.). Modelis $M T 3 D$ nodrošina vielu masas pārneses modelēšanu (VAV masas un koncentrācijas izmaiņa laikā un telpā). Parasti vispirms darbina $M O D P A T H$, lai iegūtu datus $M T 3 D$ vadības parametru pareizai izvēlei.

Detalizētāku informāciju par Inčukalna HM var atrast pārskatā [1].

\section{LITERATŪRAS SARAKSTS}

[1] A. Spalvinšš, Ziemelu un Dienvidu sērskābā gudrona dīku pazemes ūdeņus piesārṇojošo vielu masas transporta matemātiskā modelēšana, Pārskats pakalpojumu līgumam ar personu apvienību "INTERGEO", Rīga, marts, 2016, 31, lpp. teksta, 79 att., 8 pielikumi. (in Latvian)

[2] Environmental Simulations, Inc., "Groundwater Vistas. Version 6, Guide to using," 2011.

[3] W. Harbaugh, "MODFLOW-2005, U.S. Geological Survey Modular Ground-Water Model: the ground-water flow process," ch. 16, book 6, US Geological Survey Techniques and Methods 6-A16, USGS, Reston, VA.

[4] D. W. Pollok, "User's Guide for MODPATH/MODPATH-Plot, Version3. A particle tracking post-processing package for MODFLOW, the US Geological Survey finite-difference groundwater flow model, U.S. Geological survey,” September 1994. 
[5] C. Zheng, "MT3D99 A modular three dimensional transport model for simulation of advection, dispersion and chemical reactions of contaminants in groundwater systems," USEPA report, USEPA, Washington, DC, 1999

[6] Golden Software, Inc., "SURFER-12 for Windows, Users manual, Guide to Using," 2015.

[7] A. Spalviñ̌s, Piesārṇoto vietu - Inčukalna gudrona dīḳi un Olaines šḳidro toksisko atkritumu izgāztuve, sanācijas projekta sagatavošana, Atskaite līgumam Nr. VP461/195 starp Valsts SIA 'Vides projekti”' un Rīgas Tehnisko universitāti, Rīga, Aprīlis, 2005, 39 lpp. (in Latvian)

[8] I. Semjonovs, Piesārnnošanās un pašattīiñ̌sanās procesi pazemes ūdenos, Latvija, Rīga, Zinātne, 1995, 121. lpp. (in Latvian)

[9] Gidrogeologija SSSR., tom HHHI, Latvjskaja SSR., I čast., Moskva: Nedra, 1967, p. 200.

[10] A. Spalviņ̌š, Rīgas Tehniskās universitātes atskaite par līgumdarba Nr. 116/3k izpildi. Piesārṇojošo vielu bilances un transporta matemātisko modeḷ izveide Inčukalna sērskābā gudrona atkritumu dīḳu teritorijām., Rīga, 1998.g. (in Latvian)

[11] Inčukalna Ziemel̦u izgāztuves hidrauliskais modelis. Baltec Associates, INC. atskaite, Rīga, 1995, 52 lpp.(in Latvian)

[12] Piemēroto vietu izvēle gudrona atkritumu iekapsulēšanai., SIA GEO CONSULTANTS atskaite par inženierǵgeoloğiskajiem pētījumiem Inčukalna apkaimē 1997.-1998. gados, Rīga, 1998. gada septembris, 34 lpp. ar tekstu un grafiskiem pielikumiem. (in Latvian)

[13] A. Spalviņ̌̌, Ziemeḷu sērskābā gudrona dīḳa pazemes ūdeņus piesārnojošo vielu masas transporta matemātiskā modeḷa izveide un priekšlikumu sagatavošana optimālas pazemes ūdenu sanācijas sistēmas izveidei, atskaite līgumam starp SIA "Eiroprojekts" un RTU, 2012. gada, jūnijs, Rīga, 37 lpp. teksta un pielikumi. (in Latvian)

[14] A. Spalvinuš, Latvijas hidroǵeologiskā modeḷa LAMO pilnveidošanas starprezultāti, Pārskats līgumam 2014/15 starp LVG̣MC un RTU, Rīga, 2015. g. novembris, vad. A. Spalvinnš, teksts 30 lpp, pielikumi 53 lpp. (in Latvian) [Online]. Available: http://www.emc.rtu.lv/VPP/ATSK LVGMC 2015 teksts.pdf

http://www.emc.rtu.lv/VPP/ATSK_LVGMC_2015_pielikumi.pdf
Aivars Spalviņš is Head of the Environment Modelling Centre of RTU. His research interests include computer modelling of groundwater flows and migration of contaminants.

E-mail: Aivars.Spalvins@rtu.lv

Inta Lāce is a Researcher with the Environment Modelling Centre, Faculty of Computer Science and Information Technology, RTU.

E-mail: intalace@yahoo.com

Kaspars Krauklis is a Researcher with the Environment Modelling Centre of Riga Technical University.

E-mail: kasparskrauklis@gmail.com

Tatjana Sorokina is a Hydrogeogolist of the INTERGEO BALTIC Ltd., Latvia.

E-mail: tatiana.sorokina@intergeo.com

Henning Wallner is the Chairman of INTERGEO Environmental Technology, Austria.

E-mail: henning.wallner@intergeo.com

Modelling of Contaminant Mass Transport in Groundwater Flow Polluted by Sulphuric Goudron Pools of Incukalns Aivars Spalviṇš ${ }^{1}$, Inta Lāce ${ }^{2}$, Kaspars Krauklis ${ }^{3}$, Tatjana Sorokina ${ }^{4}$, Henning Wallner ${ }^{5}$

${ }^{1-3}$ Riga Technical University, Latvia, ${ }^{4,5}$ Intergeo Baltic Ltd.

At the Incukalns district, two abandoned gravel pits from 1955 to 1970 were used as dump sites for storing liquid sulphuric goudron (mixture of sulphuric acid and oil products). The dump sites were named the Northern and Southern pools. The Northern pool was filled with sand. Presently, the Southern pool contains goudron in the state of liquid, paste and stone. During sixty years, the pools are polluting groundwater that moves towards the Gauja river. Excavation of the goudron body of the Southern pool continues. The contaminated sand of the Northern pool will be taken away. In order to optimize the ongoing process of environmental recovery of the place, the researchers of Riga Technical University carried out computer based modelling of mass transport of contaminants (especially surface active substances (SAS)) by the groundwater flow. The research was done to the request from the company INTERGEO. It was found out that the SAS plumes of the Northern and Southern pools will reach the river, after 25 and 80 years (from 2015), accordingly. The SAS mass of the plumes was evaluated, respectively, $8000 \mathrm{~kg}$ and $30000 \mathrm{~kg}$, for the Northern and Southern pool in 2015. The rate of the SAS inflow from the Northern pool plume into the Gauja river was estimated for $2039-2099$ if no SAS destruction takes place: $660 \mathrm{~kg}$ - in 2039-2054; $2800 \mathrm{~kg}$ - in 2059-2079; $4000 \mathrm{~kg}$ - in 2079-2099. After 2119 , the mass of zone SAS plume will be $540 \mathrm{~kg}$. The unevenness of the SAS inflow rate is due to the smaller SAS concentration for the exterior part of the plume than for its central part. This fact was also confirmed by the hydrographs for the SAS concentration of the virtual monitoring wells. It was found that the SAS inflow into the Gauja river will have no real influence (even without SAS destruction) on the quality of river water, because its flow is much more stronger than that of the contaminated groundwater flow from the Northern pool.

Keywords - hydrogeological model, modelling of contaminant mass transport, surface active substance. 